\title{
高分子フィルムの付着カを利用したシリコン表面上の微粒子除去
}

\author{
高橋 主人*,**
}

\section{Removal of Glass Particles from a Silicon Surface by Adhesive Force of Polymer Films}

\author{
Kazue Takahashi, ${ }^{* * *}$
}

Received 28 March 2017; Accepted 11 July 2017

\begin{abstract}
Fine spherical glass particles on a $\mathrm{Si}$ substrate were removed using the adhesive force between them and a polyethylene (PE) film or polyurethane (PU) rubber sheet. The PE film or PU rubber sheet was placed on the Si substrate on which spherical glass particles with a diameter of $0.3-1.5 \mu \mathrm{m}$ were adhered. The film/sheet was pressed onto the Si substrate using electrostatic force or pressurized air. When the force between the film/sheet and the particles became larger than that between the Si substrate and the particles, the particles were removed from the substrate along with the film/sheet. A repetition of this process led to the removal of all the glass spheres. More than $80 \%$ of the particles were removed in the first removal step when the pressure was $0.1 \mathrm{MPa}$ and more than $0.25 \mathrm{MPa}$ in the case of the PU rubber sheet and PE film, respectively.
\end{abstract}

Keywords: Particle removal, Dry cleaning, Particle adhesion, Polyethylene film, Polyurethane rubber.

\section{1. 緒言}

種々の部品等に付着した微粒子の除去は，半導体製造 や食品業界，医薬品業界などにおいて，製品の品質や歩 留まりに影響するため, 解決すべき重要な技術課題となっ ている。特に半導体製造においては年々微細化が進むた め，製造装置の部品等に付着した除去すべき微粒子のサ イズも年々減少し, 2017 年には $0.01 \mu \mathrm{m}$ に達している[1]。 $0.1 \mu \mathrm{m}$ 以下の微粒子を除去するため, ウエハ洗浄で は, メガソニック洗浄[2,3], 機能水や蒸気洗浄, 極低温 エアロゾル洗浄[4], レーザー洗浄[5], ガスクラスターイ オンビーム洗浄[6]などが開発され, 一部は実用化されて いる。しかしながら，これらの洗浄技術は平坦で定形の ウエハを対象としており，形状等が多様な部品洗浄には 適用しにくいものが多い。

部品洗浄には, 超音波洗浄や酸洗浄, アルカリ洗浄, 純水洗浄などのウエット洗浄が多用されている。超音波 洗浄で効果的に除去できる粒子サイズは，部品表面で洗 浄液が停滞し流体力がほとんど作用しなくなる境界層の 厚さよりも大きな微粒子である[7]。そのため, 洗浄可能 な微粒子サイズは, 超音波周波数が数 $10 \mathrm{kHz}$ では数 $\mu \mathrm{m}$

大島商船高等専門学校

（７42-2193 山口県大島郡周防大島町大字小松 1091 番地 1)

National Institute of Technology, Oshima College

(1091-1 Komatsu Suooshima-cho, Oshima, Yamaguchi 742-2193, Japan)

* Corresponding Author ktakahashi@kpb.biglobe.ne.jp

** 現在の連絡先（７ 744-0013 山口県下松市栄町 2-2-26）
程度, 1 $2 \mathrm{MHz}$ のメガソニック洗浄でも $0.2 \mu \mathrm{m}$ 程度で ある。したがって, $0.1 \mu \mathrm{m}$ 以下の微粒子を除去するため には，種々の洗浄法を組み合わせて繰り返し洗浄するこ とになり, 純水消費量や廃液処理の増加による環境負荷 が大きい。

以上のような状況から, 部品に付着した $1 \mu \mathrm{m}$ 以下の 領域の微粒子を除去できる新たな技術が必要とされてい る。また, 環境負荷の改善を図る上で, 純水や溶剤を用 いないドライ洗浄が着目される。部品用のドライ洗浄に は, ドライアイス洗浄 [8,9], 高速気流洗浄[10], 気流中 に薄片を混入した洗浄[11], 静電気を利用した洗浄[1214], 粘着フィルムやゴム, スポンジなどに微粒子を付着 させて除去する洗浄方法などがある。

静電気を利用して誘電体フィルムに微粒子を付着させ て除去する方法では, Cooper 等 $[15,16]$ が $0.5 \mu \mathrm{m}$ 以上の微 粒子が除去できたと報告している。また，パルス状の高 速気流洗浄ではミクロン領域の除去性能が報告[17]され ている。しかしながら, 他のドライ洗浄については対象 とする微粒子サイズやその除去特性が不明な場合が多い。

Cooper 等の方法は, 被洗浄試料に対向して電極を設置 し, 試料と電極の間に高電圧を印加して微粒子を除去す る。試料と電極は非接触で狭い間隔に保たれ, 電極間に 挿入した誘電体フィルムに微粒子を付着させて回収する。 微粒子除去は高電圧を印加した状態で実施される。この ような方法は, 高電圧印加に付随する安全対策が必要で あることや, 試料と電極との間隙を保つための工夫が必 要であることなど，簡易的にドライ洗浄を実施する上で 
改善すべき点がある。そこで，筆者は，簡便なドライ洗 浄技術の開発 $[18,19]$ を行ってきた。試料・誘電体フィル ム・電極という構成は Cooper 等と同じであるが, 試料と 電極間の距離を保つことをせず, 試料と誘電体フィルム および誘電体フィルムと電極が互いに接触するようにし た。試料と電極間に高電圧を印加すると静電気力により 誘電体フィルムが試料に押し付けられ，試料表面の微粒 子と誘電体フィルムが接触する。高電圧を切断した後も 微粒子がフィルムに付着した状態で除去される。その結 果, $1 \mu \mathrm{m}$ 以下の粒子の除去は可能であるが, 除去操作を 繰り返す必要があることを明らかにした。2〜20 $\mu \mathrm{m}$ の微 粒子に対しては, 除去操作を数回繰り返すと約 $80 \%$ の除 去率が得られ，0.3〜 $1.5 \mu \mathrm{m}$ の微粒子に対しては, 10 回 程度の繰り返し操作で 80\%の除去率が得られている。

これまでは, 誘電体フィルムを微粒子に押し付けると きに静電気力を利用してきたが，高電圧を切断した状態 でも微粒子はフィルムに付着して除去されており，静電 気力は単にフィルムを微粒子に押し付けるだけの効果し かないとも考えられる。本報告では，静電気力以外の方 法でフィルムを試料に押し付けるとともに，さらなる除 去率の向上を目指し，フィルムの材質とフィルム押付力 が微粒子除去率に及ぼす影響について評価した結果を述 ベる。

\section{2. 実験方法}

\section{1 微粒子除去試験装置}

微粒子除去は，試料にフィルムを被せて押圧すること により, 試料に付着していた微粒子をフィルムに付着さ せて除去する。試料にフィルムを押圧する手段として, 静電気力の代わりに空気圧を利用した Fig. 1 の加圧式装 置を主として用いた。その他，試料にフィルムを押圧す る手段として, 試料の上にフィルムと電極を置き試料と 電極間に高電圧を印加する静電気力方式（Fig. 2）や，家 庭用の真空パック器（Fig. 3）も一部使用した。

Fig. 1 の装置では, 微粒子の付着した試料の上にフィ ルムを被せ，その上から装置の上部を組み付ける。試料

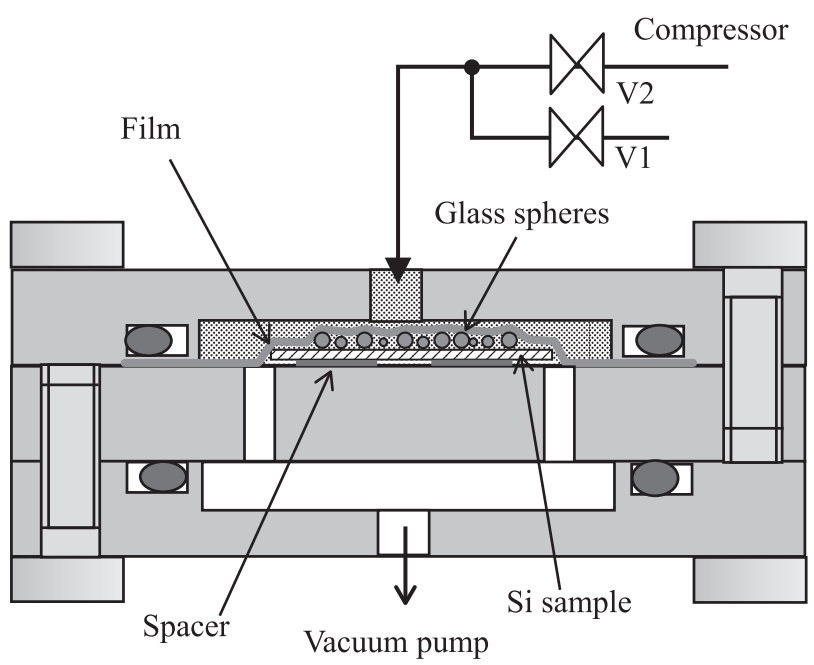

Fig. 1 Apparatus for applying high pressure to the film/sheet

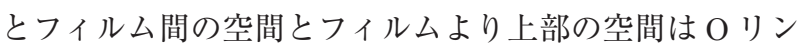
グでシールされ隔離されている。バルブ V1 を開けた状 態で試料とフィルム間の空間を真空排気すると, フィル ムは大気圧で試料に押付けられる。フィルムの押付力が 大気圧の場合は, 真空排気を 60 秒間継続した後, 大気開 放してフィルムを剥がす。

押付力を大気圧以上とする場合は, 真空排気した後に バルブ V1 を閉じてフィルムの上面にコンプレッサーか らの高圧空気を 60 秒間負荷する。その後バルブ V1 開 いてフィルム表面を大気圧に戻し, 装置の上部を取り外 す。さらに真空排気を停止して大気圧に戻した後，フィ ルムを剥がすと微粒子がフィルムに付着して除去される。

真空ポンプの排気速度は $7 \mathrm{~L} / \mathrm{min}$, 到達圧力は $0.00665 \mathrm{MPa}$ である。加圧には最高圧力 $0.78 \mathrm{MPa}$ (ゲー ジ圧）のコンプレッサーを用いた。

押付力に静電気力を利用する場合は, Fig. 2 に示した 装置を用いる。アルミニウム板の上に導電性両面テープ で試料を貼付する。試料の上に誘電体フィルム, 上部シ リコン電極, 重りを置く。アルミニウム板と上部シリコ ン電極の間に高電圧を印加すると, 誘電体フィルム（除 去用フィルム）は静電気力によって微粒子に押し付けら れる。所定時間が経過した後に印加電圧を切断し, 重り と上部シリコン電極を取り除きフィルムを剥がす。微粒 子はフィルムに付着して除去される。フィルムの押付力 は印加電圧で制御される。印加電圧が高過ぎるとフィル ムが絶縁破壊するため, 本実験で用いた厚さ $0.03 \mathrm{~mm}$ の ポリエチレンフィルム対しては $3 \mathrm{kV}$ が限界で, 最大押付 力は約 $0.1 \mathrm{MPa}$ であった。

家庭用の真空パック器を用いた微粒子除去では, Fig. 3 に示すように，真空パック専用の袋を使用する。袋の中 に試料とフィルムを挟んで入れ，袋の内部を減圧するこ とで大気圧により試料にフィルムを押し付ける。袋には

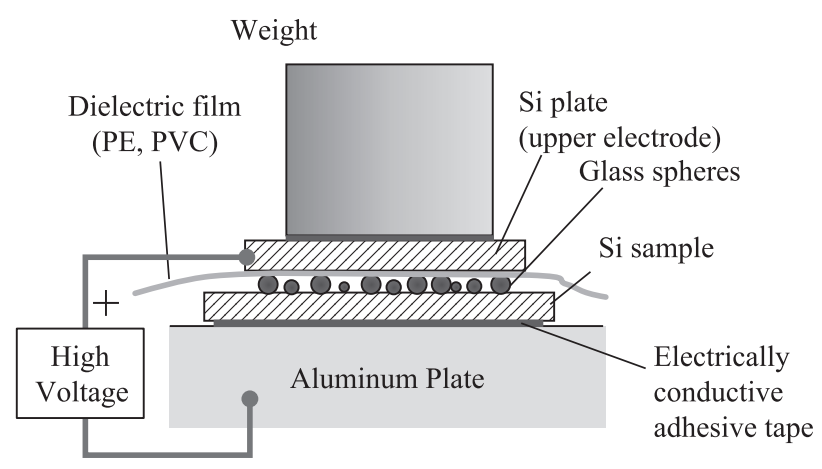

Fig. 2 Particle removal apparatus by using electrostatic force

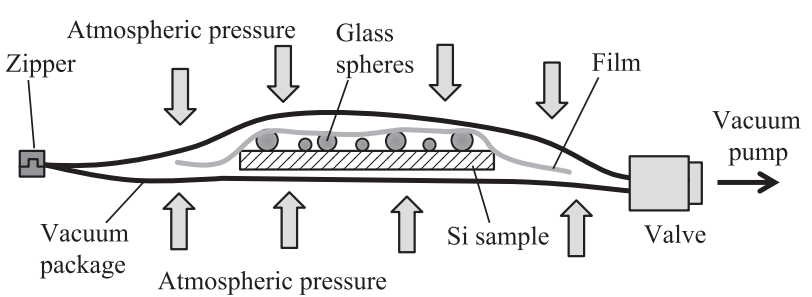

Fig. 3 Schematic of a vacuum packer 
試料を出し入れするファスナーと，逆止弁付きの真空排 気ノズルが取り付けられていて, 専用の真空ポンプで排 気する。微粒子除去試験では, 60 秒間真空排気した後, 大気開放し, 微粒子をフィルムに付着させて除去した。 この場合は, 真空パック内の圧力と大気圧の差圧で試料 にフィルムを押し付けることになる。使用した真空パッ ク器の到達圧力は $0.049 \mathrm{MPa}$ であり, 押付力は $0.052 \mathrm{MPa}$ である。

\section{2 微粒子付着試料の作製}

微粒子を付着させた試料は, 厚さ $0.725 \mathrm{~mm}$ のシリコ ンウエハ $(\mathrm{Si})$ を約 $15 \mathrm{~mm}$ 角にカットしたものである。 試料粒子は, 粒子径 $0.3 \sim 1.5 \mu \mathrm{m}$ の溶融シリカ $\left(\mathrm{SiO}_{2}\right.$, 日 本粉体工業技術協会製サブミクロン領域試験用粒子 STP0.3-1.5）を用いた。

試料への微粒子の分散付着は，気流による微粒子分散 装置の文献[20,21]などを参考にして自作した分散器を使 用した。Fig. 4 に細管分散器を示す。細管分散器は，高 圧窒素供給系，微粒子の収納容器，細管，ノズル，フー ド (PET ボトル), フード内の衝突板, 高電圧が印加で きる試料台, 高電圧電源から構成される。

細管は内径 $4 \mathrm{~mm}$ の塩化ビニルチューブで長さが 1 〜 $2 \mathrm{~m}$ である。細管両端のノズルはポリエチレン製で内径 $2 \mathrm{~mm}$, 長さ $26 \mathrm{~mm}$ の円筒形である。微粒子の供給量は 10〜 $50 \mathrm{mg}$, 高圧窒素ガスはゲージ圧で $0.1 〜 0.3 \mathrm{MPa}$, 試料とフード間の距離は $0 \sim 80 \mathrm{~mm}$ として条件出しを 行った。

窒素ガスを導入すると, 微粒子は気流に乗ってビニル チューブ内からフードへと搬送される。このとき凝集し ていた微粒子は互いの衝突等で分散され，ノズルから気 流とともに噴き出されて試料に付着する。ところが，試 料に到達した大きな微粒子は試料表面でリバウンドして 飛散し，微細な粒子は気流に乗って飛散するため，実際 に付着する微粒子は少ない。微粒子は帯電していると考 えられるので, 試料に正の高電圧 $5 \mathrm{kV}$ を印加したとこ ろ, 微粒子の付着数を増すことができた。さらに, フー ドの中に衝突板を挿入することで分散性の改善が図れた。 衝突板は直径 $20 \mathrm{~mm}$ の円板と直径 $10 \mathrm{~mm}$ の孔が開いた 円板を $15 \mathrm{~mm}$ 隔てて 2 段式にしている。最終的には，微

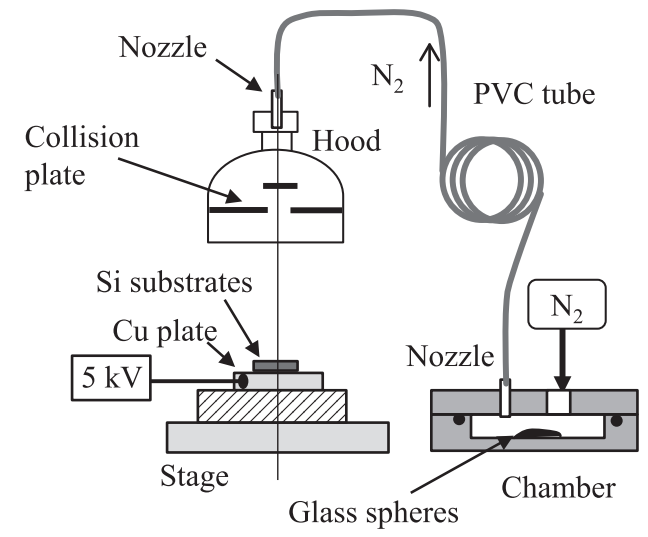

Fig. 4 Schematic of a disperser
粒子 $10 \mathrm{mg}$, 供給圧力 $0.3 \mathrm{MPa}$ (高圧窒素ガス, ゲージ 圧), 試料とフード間距離 $80 \mathrm{~mm}$, 試料への印加電圧 $5 \mathrm{kV}$ の分散条件とした。微粒子密度は数 1000 個 $/ \mathrm{mm}^{2}$ である。 $\mathrm{Si}$ とガラス球の付着力を安定化させるため, 室温, 相 対湿度 20〜30\%で 1 週間以上保管してから除去試験に供 した。

\section{3 微粒子除去用フィルムの選定}

微粒子をフィルムに付着させて除去する場合, 微粒子 とフィルム間の付着力は大きい方が望ましいと考えられ る。そこで, Si とフィルム間の付着力を測定して, フィ ルムの特性を把握することにした。被着材は, 平坦で清 浄な試料が望ましいと考え，Si 用いた。

付着力測定装置の概要を Fig. 5 に示す。ベースプレー トの上にポリカーボネート板（厚さ $10 \mathrm{~mm}$ ) を固定し, その上に約 $100 \mathrm{~mm}$ 角の $\mathrm{Si}$ を接着剤にて貼付した。その 上にフィルムと重りを置く。重りは真ちゅう製で, 下端 に $\mathrm{Si}$ (面積 $2 \mathrm{~cm}^{2}$ 程度) が接着剤にて貼付してある。重 りは上部のロードセル（容量 $20 \mathrm{~N}$ または $100 \mathrm{~N}$ ）にナイ ロンロープで接続されている。ロードセルはモーター駆 動の上下機構（図示せず）に接続されている。

$\mathrm{Si}$ 間にフィルムを挟み, 重りの自重で $\mathrm{Si}$ とフィルムが 押し付けられた状態で所定の時間保持し，上下機構によ りロードセル側を持ち上げて Si とフィルム間の付着力を 測定した。

フィルムは, 低密度ポリエチレン $(\mathrm{PE}$, 厚さ $0.03 \mathrm{~mm})$, 軟質ポリ塩化ビニル (PVC, 厚さ $0.1 \mathrm{~mm}$, 剥離用の微粒 子は付着していない), 導電性ポリウレタンゴム（PU, 厚さ $1 \mathrm{~mm}$ ) とした。試験条件は, 室温 $21 \sim 22{ }^{\circ} \mathrm{C}$, 相対 湿度 19〜46\%で，引き剥がし速度は PE，PVC，PUでそ れぞれ $0.9, \quad 0.5, \quad 0.4 \mathrm{~mm} / \mathrm{s}$ である。また, 重りの自重に よる押付力 (面圧) は, PE, PVC, PUでそれぞれ 0.032， $0.031 ， 0.026 \mathrm{MPa}$ である。フィルムによって押付

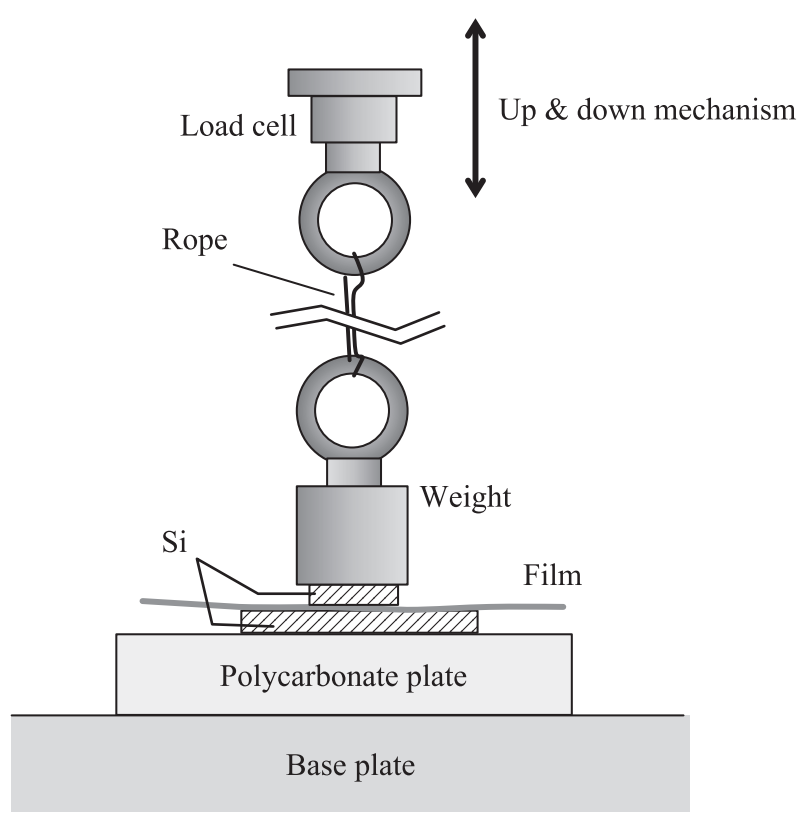

Fig. 5 Apparatus for measuring the removal forces between silicon and films 
力（面圧）が異なっているのは，重り下端の $\mathrm{Si}$ を破損な どで交換した際の Si 面積の違いによる。

試験結果を Fig. 6 に示す。図の横軸は, 重りの自重を 負荷している保持時間である。保持時間が長くなるにつ れて付着力が増加する傾向が認められる。保持時間 $60 \mathrm{~s}$ 付近で付着力を比較すると, PE で $0.001 \mathrm{MPa}, \mathrm{PVC}$ で $0.05 \mathrm{MPa}, \mathrm{PU}$ で $0.15 \mathrm{MPa}$ である。この結果から, 微粒 子除去用のフィルムとしては, PU が最も望ましく, PVC, PE と続くと思われる。なお, PVC は付着力も大 きく除去用フィルムとして適していると考えられるが, 表面が清浄なフィルムを入手できなかったため使用を断 念し，PUと PE を除去用フィルムとした。

\section{4 微粒子除去フィルムと微粒子除去率}

微粒子の除去用フィルムは，表面が清浄でなければな らないが，容易に入手できたのは，低密度ポリエチレン （PE）と導電性ポリウレタンゴム（PU）（市販の異物除去 シート) である。また, PE は付着力が小さく $\mathrm{PU}$ は大き い。両者の差による微粒子除去への影響も評価すること にし，除去用フィルムにPEと PUを選択した。使用した $\mathrm{PE}$ は厚さ $0.03 \mathrm{~mm}, \mathrm{PU}$ は厚さ $1 \mathrm{~mm}$ である。

試料上の微粒子は，ディジタルマイクロスコープ（倍 率 2000 倍）で観察し, 画像解析（Image J）で微粒子の サイズと個数を計数した。倍率 2000 倍での実画面サイズ は, 縦 $0.113 \mathrm{~mm}$, 横 $0.153 \mathrm{~mm}$ であり, 観察面積は 1 画

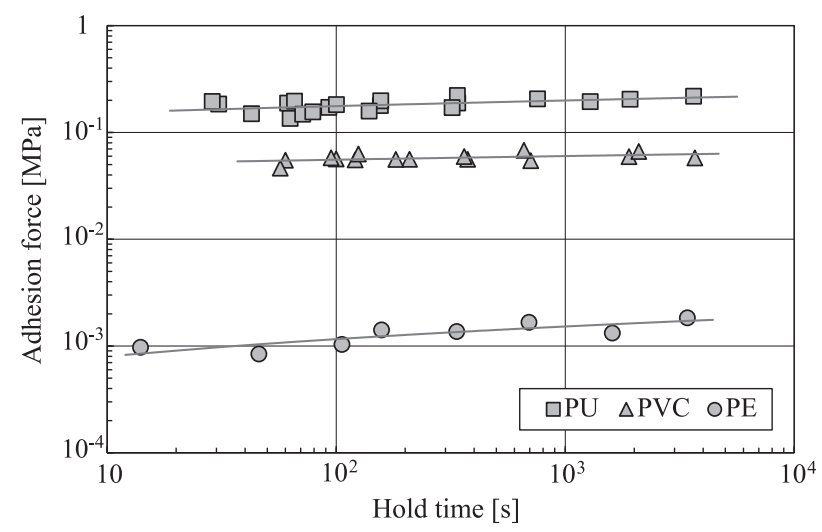

Fig. 6 Adhesion forces between silicon and PE, PVC or PU

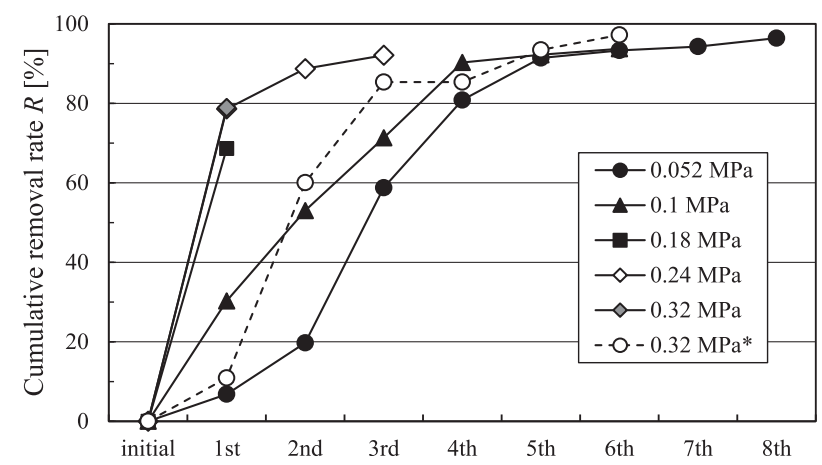

(a) PE film
面当たり $0.0173 \mathrm{~mm}^{2}$ である。試料の表面に, 直径 $0.5 \mathrm{~mm}$, 高さ $1 \mu \mathrm{m}$ の円形凸部をプラズマエッチングで 形成し, 除去試験の前後で同じ個所の微粒子が観察でき るようにした。 1 試料当たりの総観察面積は $0.173 \mathrm{~mm}^{2}$ である。試料の除去率 $R_{i}$ は, 除去操作前の微粒子数 $N_{0}$ と除去処理後の微粒子数 $N_{i}$ から次式により求めた。

$$
R_{i}=\frac{N_{0}-N_{i}}{N_{0}} \times 100 \%
$$

上式は除去操作を $i$ 回繰り返し実施した場合の累積除 去率であり,ここでは単に除去率と呼ぶ。

\section{3. 実験結果および考察}

\section{1 微粒子除去試験}

加圧式装置による微粒子除去試験結果を Fig. 7-a, Fig. 7-b に示す。Fig. 7-a は PE，Fig. 7-b は PUによる試験 結果である。なお, フィルムの押付力が $0.052 \mathrm{MPa}$ のデー 夕は真空パック器を使用した結果である。また, Fig. 7-a で $0.32 \mathrm{MPa}$ としたデー夕は, 凝集部が付着していたも のである。

$\mathrm{PE}$ で押付力が $0.052 \mathrm{MPa}$ と凝集部がある場合は, 1 回 目の除去操作による除去率が低く，2 から 3 回目以降で 除去率が向上した。押付力が $0.1 \mathrm{MPa}$ 以上では，除去率 が 80\%程度までは除去操作の繰り返し数とともに除去率 が向上し，80\%を越えると除去率は増加しにくくなった。 押付力が大きいほど $80 \%$ 台を得るための除去操作数が減 少した。

$\mathrm{PU}$ の場合は押付力 $0.1 \mathrm{MPa}$ の除去操作 1 回で除去率 $80 \%$ 以上が得られた。また，除去試験後のPUには，凝 集したままで除去されている微粒子も観察された。

静電気力を利用せず単にフィルムを試料に押し付ける だけでも微粒子の除去ができた。また, フィルムの付着 力が大きい PUが, 付着力の小さい PEより除去特性に優 れることがわかった。

\section{2 微粒子除去率に及ぼす押付力の影響}

フィルムの押付力が除去効率に及ぼす影響を，押付力 と 1 回目の除去率の関係として Fig. 8 に示す。眓中で

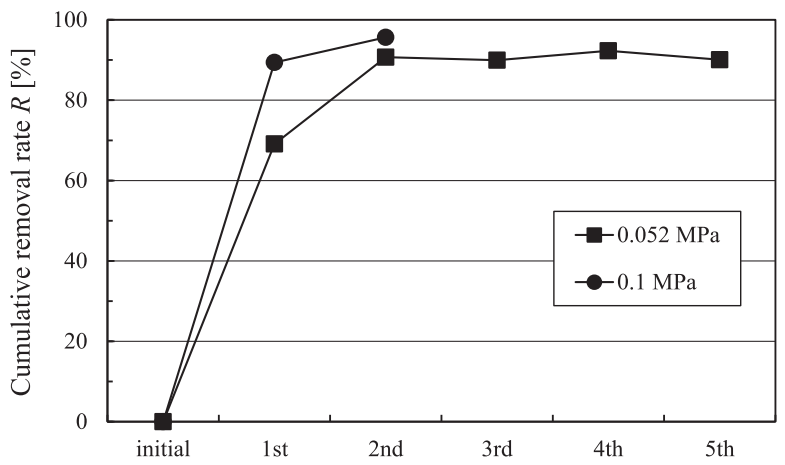

(b) PU rubber sheet

Fig. 7 Cumulative removal rate of the glass spheres with a diameter of $0.3-1.5 \mu \mathrm{m}$ for each removal step by using a PE film or a PU rubber sheet 
Agglomerate と矢印で示したものは試料に凝集部があった もので, 1 回目の除去率が極端に低い。また, 図には Fig. 7-a, -bの結果に加えて, 静電気力を利用した場合 $(\mathrm{PE}(\mathrm{HV}))$ と, 真空パック器を用いた場合 (PE(VacPack)) も追記した。

PE では, 1 回の除去操作で $80 \%$ 以上の除去率が得られ るのは押付力 $0.25 \mathrm{MPa}$ 以上の場合である。それ以上押付 力を増しても除去率は増加しない。また, 押付力が $0.25 \mathrm{MPa}$ 以下では, デー夕のばらつきはあるが, 押付力 に比例して除去率が向上している。一方, PUの場合は $0.1 \mathrm{MPa}$ の押付力で除去率 $80 \%$ 以上が得られた。

図を見る限り, 押し付け手段による除去率の差は認め られない。静電気力方式では, 微粒子とフィルムは誘電 分極で互いに引き合うため，微粒子除去に影響を及ぼす のではと思われたが, そのような効果は認められなかっ た。実際の除去操作が高電圧を切断した状態で実施され たためと思われる。

PEによる凝集部の除去率が低いのは, 凝集部の最表面 にある微粒子とフィルムとが接触することによって発生 する付着力と, 凝集部内で接触している微粒子同士の付 着力および微粒子と試料との付着力のどちらが大きいか によると考えられる。PE はPUに比較して変形しにくい ので, PE と最表面粒子との接触面積が比較的狭く, かつ 互いの付着力も小さい。そのため, 凝集部の最表面の微 粒子のみが除去されたと考えられる。この場合, 見かけ 上の除去率は変わらない。

一方, PUはPEより変形しやすいため, 接触部が凝集 部全体に広がり, 付着力も大きいので, 凝集部がそのま ま除去されたと考えられる。

押付力の負荷方法に関しては, 静電気力による押付力 は印加電圧で自由に変えることができるため便利である が, $0.1 \mathrm{MPa}$ 以上（印加電圧 $3 \mathrm{kV}$ 以上）負荷するのは, PE が絶縁破壊するため難しい。加圧式は, 部品の形状に よらずフィルムを押し付けられるのと, 比較的大きな力 も負荷することができる。これらのことを考慮すると， 負荷方式としては加圧式の方が望ましいと思われる。

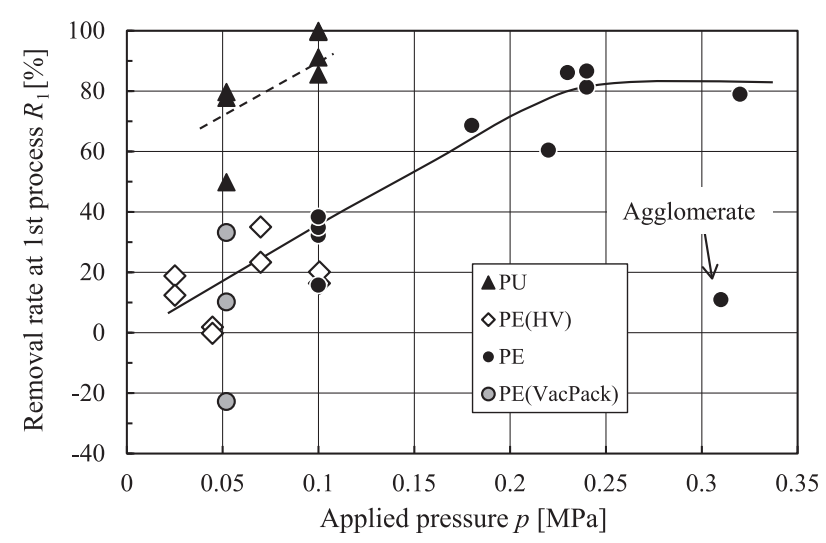

Fig. 8 Applied pressure as a function of the removal rate of the glass spheres $(0.3-1.5-\mu \mathrm{m}$ diameter $)$ during the first removal step in the case of the 0.03 -mm-thick PE film and 1.0-mm-thick PU rubber sheet

\section{3 微粒子除去のメカニズム}

PE と PU では除去効率はPU の方が良い。この理由と して, PEより PUの方が変形しやすいため, 同じ押付力 でもフィルムと微粒子との接触面積が PU で広くなるこ とや，フィルムと微粒子の付着力が PU で大きいことも 影響している。Fig. 6 によれば, Si と PEの付着力は $0.001 \mathrm{MPa}$ であったのに対し, Si と PUでは $0.15 \mathrm{MPa}$ で ある。ガラス球 $\left(\mathrm{SiO}_{2}\right)$ とフィルムの付着力も $\mathrm{Si}$ とフィ ルムのそれと同じ程度とすると, 同じ接触面積であって も，100 倍以上も PU の付着力が大きいことになる。こ の差が除去率の違いに影響していることは十分考えら れる。

除去操作の繰り返しにつれて除去率が増加する現象は, 大小の微粒子が近接している場合の除去状況を観察する ことにより, 大きな微粒子から順に除去されることと関 連している $[18]$ 。微粒子の除去にはフィルムと微粒子が 直接接触する必要がある。したがって, 大きな微粒子に 近接して付着している小さな微粒子は, フィルムに直接 接触できないか接触できたとしても押付力が小さくなる。 その結果, 大きな微粒子が先に除去され, 小さな微粒子 を除去するには次の除去操作が必要になる。

実際の除去操作では, 微粒子とフィルムの接触に伴う van der Waals 力 (vdW 力) や高分子と微粒子間の水素結 合などの化学的な付着力で微粒子除去が進行する。いず れにしても, フィルムと微粒子が接触することが重要で あり, 繰り返し除去操作が必要になる主たる原因である。

フィルムに微粒子を付着させて除去できるか否かは, 試料と微粒子の付着力と, 微粒子とフィルムとの付着力 のどちらが大きいかに依存する。どの程度の大きさなら 微粒子が除去されるかを検討してみる。微粒子に作用す る付着力には $\mathrm{vdW}$ 力, 液架橋力, 静電気力, および水素 結合などの化学的付着力が考えられるが, ここでは, 試 料を $30 \%$ RH 以下の相対湿度で保管していることから液 架橋力はそれほど大きくないとみなし, $\mathrm{vdW}$ 力のみに着 目する。

Si とガラス球およびガラス球とフィルムの間の vdW 力で比較してみる。微粒子の付着力については種々の理 論が提案[22]されているが, ここでは弾性変形を考慮し た次の Dahnekeの式[23]を用いる。

$$
\begin{aligned}
& F_{i j}=-\frac{H_{i j} d}{12 x^{2}}\left(1+\frac{H_{i j}{ }^{2} k^{2}}{108 x^{7}} d\right) \\
& k_{i j}=\frac{1-\nu_{i}^{2}}{E_{i}}+\frac{1-\nu_{j}^{2}}{E_{j}}
\end{aligned}
$$

ここで, $F_{i j}$ は vdW 力, $H_{i j}$ は Hamaker 係数, $d$ は微粒子 径, $x$ は微粒子と表面間の距離, $v_{i}, v_{j}$ はポアソン比, $E_{i}$, $E_{j}$ は縦弾性係数であり, $F$ と $H, v, E$ の添え字 $i, j$ は微 粒子とフィルムのそれを示す。また， $k_{i j}$ は Eqs. (3)に示す 弾性に関連した係数である。 $\mathrm{Si}$ とガラス球 $\left(\mathrm{SiO}_{2}\right), \mathrm{PE}$, $\mathrm{PU}$ の $E, v$ は, $\mathrm{Si}$, ガラス球 $\left(\mathrm{SiO}_{2}\right), \mathrm{PE}, \mathrm{PU}$ の材料を それぞれ添え字 1，2，3，4で表し， $E_{1}=165.7 \times 10^{3} \mathrm{MPa}$, 
$E_{2}=71.3 \times 10^{3} \mathrm{MPa}, E_{3}=760 \mathrm{MPa}, E_{4}=5.0 \mathrm{MPa}, v_{1}=0.3$, $v_{2}=0.22, v_{3}=0.458, v_{4}=0.49$ とした $[24,25]$ 。 Hamaker 係 数は $\mathrm{Si}$ と $\mathrm{SiO}_{2}$ 間で $H_{12}=13.0 \times 10^{-20} \mathrm{~J}, \mathrm{SiO}_{2}$ と $\mathrm{PE}$ 間で $H_{23}$ $=5.8 \times 10^{-20} \mathrm{~J}$ とした $[26] 。 \mathrm{SiO}_{2}$ と $\mathrm{PU}$ 間の $H_{24}$ は不明であ るが, 高分子の Hamaker 係数は $5 \times 10^{-20} \mathrm{~J}$ 前後であること から, $\mathrm{SiO}_{2}$ と $\mathrm{PE}$ のそれと同じ $\left(H_{24}=H_{23}\right)$ と仮定した。 $\mathrm{Si}$ とガラス球間およびガラス球と PE 間, ガラス球と PU 間の $\mathrm{vdW}$ 力 $F_{i j}$ は次のようになる。なお， $x=0.4 \times 10^{-9} \mathrm{~m}$ とした。

$$
\begin{aligned}
& F_{12}=-6.77 \times 10^{-2} d\left(1+3.39 \times 10^{4} d\right) \\
& F_{23}=-3.02 \times 10^{-2} d\left(1+2.11 \times 10^{7} d\right) \\
& F_{24}=-3.02 \times 10^{-2} d\left(1+4.39 \times 10^{11} d\right)
\end{aligned}
$$

微粒子が除去されるためには $F_{12}<F_{23}, F_{12}<F_{24}$ でなけれ ばならない。そこで, $K=F_{23} / F_{12}, F_{24} / F_{12}$ とし, 微粒子径 による $K$ の変化を Fig. 9 に示す。

図によれば, PEによる微粒子除去において $K>1$ とな るのは $d>0.06 \mu \mathrm{m}$ である。また, PU では $0.01 \mu \mathrm{m}$ 以下 でも $K>1$ である。PUのようにガラス球と縦弾性係数が $10^{5}$ 倍も異なる場合に Eq. (2)が成立するのか疑問である が，あくまで目安ということで実験結果と比較してみる。

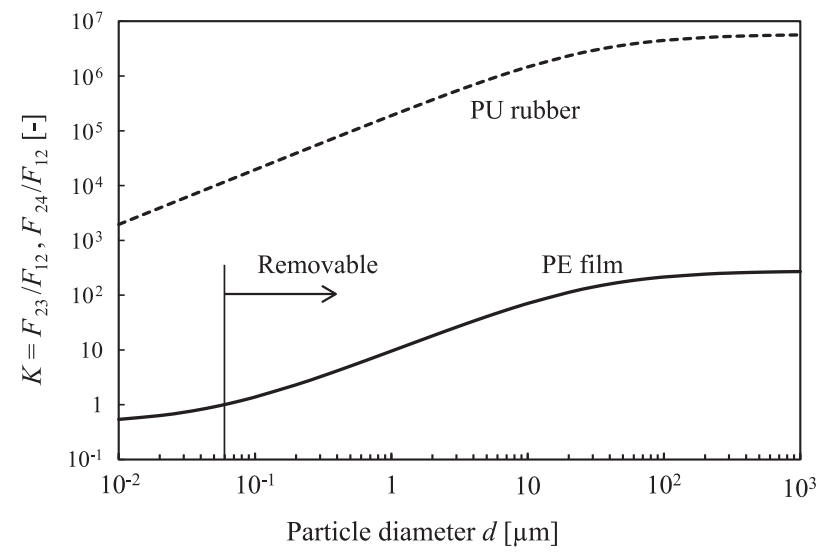

Fig. 9 Ratios of the Si-glass sphere van der Waals force to the PEglass sphere and PU-glass sphere van der Waals forces as functions of the diameter of the glass spheres

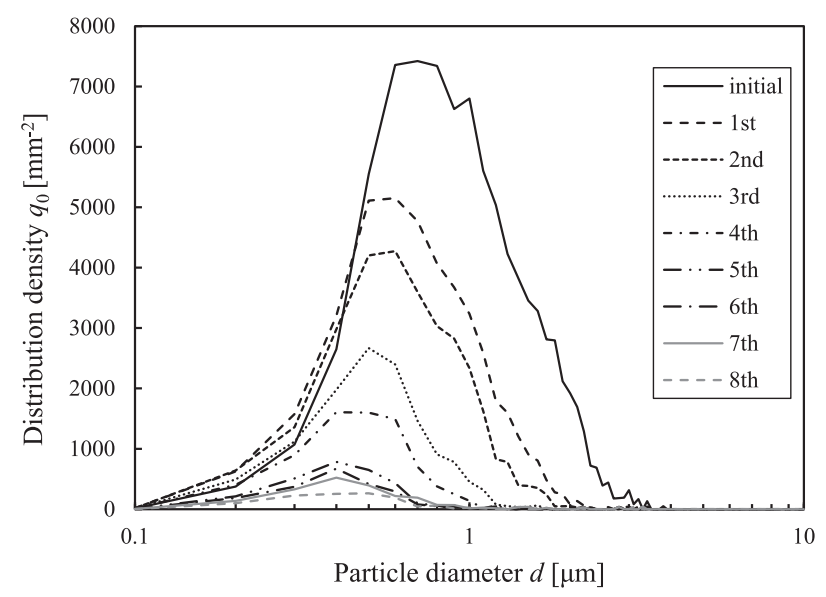

(a) PE film at $0.052 \mathrm{MPa}$
なお, $\mathrm{SiO}_{2}$ に対する $\mathrm{PE}$ と $\mathrm{PU}$ の Hamaker 係数を同じと 仮定しているので, PE と PU の縦弾性係数の差に応じ て, フィルムとガラス球の接触面積の差が Fig. 9 の結果 になっているとみなせる。計算上, PU は PE の $10^{4}$ 倍近 く接触面積が広いことに相当する。

本試験では $0.3 \mu \mathrm{m}$ 以上の微粒子が除去されることは確 認できている。それ以下の粒子径について除去できるか は不明であるが, $0.3 \sim 1.5 \mu \mathrm{m}$ の微粒子にも $0.3 \mu \mathrm{m}$ 以下 の微粒子がわずかに含まれているので, Fig. 10-a および Fig. 10-b に示した粒子径ごとの除去特性結果により考察 してみる。

Fig. 10 は各除去操作後の粒子の個数密度 $\Delta n\left[\mathrm{~mm}^{-2}\right]$ を 粒子径の分割区間（ $\Delta \log d[-] ）$ で割った個数基準頻度 $r_{0}$ $\left[\mathrm{mm}^{-2}\right]$ であり, 分割区間幅は $0.1 \mu \mathrm{m}$ とした。Fig. 10-a は PE で押付力が $0.052 \mathrm{MPa}$, Fig. 10-b は PUで押付力が $0.1 \mathrm{MPa}$ の場合である。

$\mathrm{PE}$ では, 除去操作が繰り返されるにつれて大きな粒子 が除去され, 粒子径分布のピーク径が除去に小さくなっ ている。PEに接触した大きな粒子から徐々に除去されて いく様子が伺え, $\mathrm{vdW}$ 力による微粒子除去の粒子径依存 性 Fig. 9 とも一致する。 8 回の除去操作で, $\quad 0.3 \sim 0.4 \mu \mathrm{m}$ 付近にピーク径を持つ粒子径分布となった。なお，図か らは分かりにくいが, $0.1 \mu \mathrm{m}$ 付近の微粒子も除去されて はいるので, 除去可能な微粒子径は $0.1 \mu \mathrm{m}$ 以下にある。

PUでは, PEのように大きな粒子から除去される様子 は認められず，微細な粒子も含めて一様に除去されてい る。PUの変形しやすさと付着力の大きさが微粒子除去 に寄与していると思われる。また, 図より $0.1 \mu \mathrm{m}$ 以下の 微粒子も除去されていると予想される。

本試験の範囲内では $0.1 \mu \mathrm{m}$ より微細な粒子の観察は困 難であり, PE の除去可能な粒子径 $0.06 \mu \mathrm{m}$ について確認 することはできなかった。いずれにしろ，0.1 $\mu \mathrm{m}$ 付近ま での微粒子は除去可能であることがわかった。

\section{4. 結 言}

$\mathrm{Si}$ 表面に付着した微粒子（ガラス球）をフィルムに付

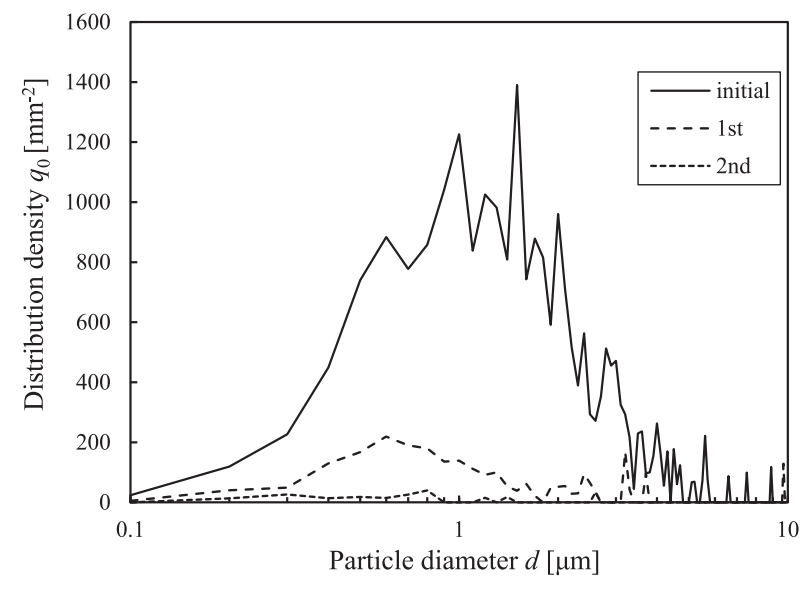

(b) PU rubber sheet at $0.1 \mathrm{MPa}$

Fig. 10 Histogram showing the number of particles removed (0.3-1.5 $\mu \mathrm{m}$ diameter) by using a PE film or a PU rubber sheet 
着させて除去する試験を実施し，以下の点を明らかにし た。

（1）微粒子の除去は，フィルムと微粒子が接触すること が重要であり, フィルムの押し付け方法には依存し ない。

（2） $0.3 \mu \mathrm{m}$ 以上のガラス球は, 低密度ポリエチレンフィ ルム（PE）および導電性ポリウレタンゴム（PU）に よって除去可能である。

(3) $0.1 \mu \mathrm{m}$ 付近のガラス球でも除去操作を繰り返すこと により除去可能である。

（4）PUの方が PEより除去特性が優れている。
（5）フィルムの押付力を増すにつれ，PEの除去特性が向 上する。

（6） 1 回の除去操作で $80 \%$ 以上の除去効率を得るには, $\mathrm{PE}$ の場合は $0.25 \mathrm{MPa}$ 以上の押付力を要し, PU の場 合は $0.1 \mathrm{MPa}$ で十分である。

本研究は JSPS 科研費 26420329 の助成を受けました。 また, 微粒子の分散付着方法等について岡山大学後藤邦 彰教授よりご教示いただきました。ここに感謝申し上げ ます。 $d \quad$ : particle diameter

$E_{i} \quad$ : longitudinal elastic constant of material $i$

$F_{i j} \quad:$ van der Waals' force between material $i$ and $j$

$H_{i j} \quad$ : Hamaker constant between material $i$ and $j$

$k_{i j} \quad:$ elastic quantity between material $i$ and $j$

$N_{0} \quad$ : initial particle number

$N_{i}$ : particle number after the $i$-th removal process

$q_{0}$ : distribution density

$R_{i} \quad$ : removal efficiency after the $i$-th removal process

\section{Nomenclature}

[m] $\quad x \quad$ : gap between particle and substrate [m]

$[\mathrm{Pa}] \quad v_{i} \quad$ : Poisson's ratio of material $i$

[J] Subscript

[1/Pa] $\quad 1$ : silicon

[-] $2: \operatorname{glass}\left(\mathrm{SiO}_{2}\right)$

[-] 3 : polyethylene

$\left[\mathrm{mm}^{-2}\right] \quad 4$ : polyurethane

\section{References}

[1] International Technology Roadmap for Semiconductors 2.0, 2015 edition, Yield Enhancement, Table YE3.

[2] M. Kazemi, H. Treichel, R. Ligutom, Substrate cleaning using ultrasonics/megasonics, Advanced Semicond. Manuf. Conf. (ASMC) 22nd Annual IEEE/SEMI, Saratoga Springs, USA (2011) p. 1.

[3] Q. Qui, G. J. Brereton, Mechanisms of removal of micronsized particles by high-frequency ultrasonic waves, IEEE Trans. Ultrason. Ferroelect. Freq. Cont., 24 (1995) 619-629.

[4] H. Lin, K. Chioujones, J. Lauerhaas, T. Freebern, C. Yu, Damage-free cryogenic aerosol clean processes, IEEE Trans. Semicond. Manuf., 24 (2007) 101-106.

[5] D. Kim, Y. Kim, J. Ryu, H. Kim, Dry cleaning technology of silicon wafer with a line beam for semiconductor fabrication by KrF excimer laser, Jpn. J. Appl. Phys., 41 (2002) 45634570.

[6] K. Dobashi, K. Inai, M. Saito, T. Seki, T. Aoki, J. Matuo, Ultrafine particle removal using gas cluster ion beam technology, IEEE Trans. Semicond. Manuf., 26 (2013) 328 334

[7] T. Azakami, H. Kikuchi, Particle removal mechanism in ultrasonic cleaning-Scrubbing action by resonant bubbles, Hyoumen Gijyutsu, 47 (1996) 37-41.

[8] R. Sherman, D. Hirt, R. Vane, Surface cleaning with carbon dioxide snow jet, J. Vac. Sci. Technol. A 12 (1994) 1876 1881.

[9] Y. Liu, D. Hirama, S. Matsusaka, Particle removal process during application of impinging dry ice jet, Powder Technol., 217 (2012) 607-613

[10] K. Gotoh, Removal of particles from solid surfaces using high speed air jet, Earozoru Kenkyu, 29 (2014) 229-235.

[11] Y. Okamoto, A. Fuchigami, T. Sato, Y. Taneda, Development of dry washing technology with thin pieces of media, Ricoh
Technical Report, 36 (2010) 53-60.

[12] T. R. Szarek, P. F. Dunn, An apparatus to determine the pulloff force of a conducting microparticle from a charged surface, Aerosol Sci. Technol., 41 (2007) 43-50.

[13] V. J. Novick, C. R. Hummer, P. F. Dunn, Minimum dc electric field requirements for removing powder layers from a conductive surface, J. Appl. Phys., 65 (1989) 3242-3247.

[14] H. Saeki, J. Ikeda, I. Kohzu, H. Ishimaru, New electrostatic dust collector for use in vacuum systems, J. Vac. Sci. Technol. A 7 (1989) 2512-2514.

[15] D. W. Cooper, H. L. Wolfe, J. T. C. Yeh, R. J. Miller, Surface cleaning by electrostatic removal of particles, Aerosol Sci. Technol., 13 (1990) 116-123.

[16] D. W. Cooper, H. L. Wolfe, J. T. C. Yeh, US4,744,833, 1988-05-17.

[17] M. Okazaki, M. Yoshida, J. Oshitani, K. Gotoh, Effect of pulsed air jet on the air jet removal of adhered single particles, J. Soc. Powder Technol., Japan, 45 (2008) 297 304.

[18] K. Takahashi, Removal of the particles on a silicon surface using electrostatic force, J. Vac. Soc. Jpn., 56 (2013) $273-$ 276.

[19] K. Takahashi, Dependence of particle size on the removal of particles on a silicon surfaces by using electrostatic force, J. Vac. Soc. Jpn., 57 (2014) 140-143.

[20] Y. Kousaka, K. Okuyama, A. Shimizu, T. Yoshida, Dispersion mechanism of aggregate particles in air, J. Chem. Eng. Jpn., 12 (1979) 152-159.

[21] G. Calvert, M. Ghadirl, R. Tweedie, Aerodynamic dispersion of cohesive powders: A review of understanding and technology, Adv. Powder Technol., 20 (2009) 4-16.

[22] C. Tsai, D. Y. H. Pui, B. Y. H. Liu, Elastic flattening and particle adhesion, Aerosol Sci. Technol., 15 (1991) 239-255. 
[23] G. Dahneke, The influence of flattening on the adhesion of particles, J. Colloid Interface Sci., 40 (1972) 1-13.

[24] National Astronomical Observatory of Japan, Chronological Scientific Tables, Maruzen Shuppan (2015) p. 393.
[25] Y. Ohtsuki, S. Koide, Butsuri Benricho, Kyoritsu Shuppan (1991) p. 35.

[26] H. J. Butt, M. Kappl, Surface and Interfacial Forces, WileyVCH Verlag GmbH \& Co. KGaA, Weinheim (2010) p. 28. 